\title{
FEEDING BEHAVIOR OF THE CIRRATULID Cirriformia filigera (DELLE CHIAJE, 1825) (ANNELIDA: POLYCHAETA)
}

\author{
PARDO, E. V. and AMARAL, A. C. Z. \\ Departamento de Zoologia, Instituto de Biologia, Universidade Estadual de Campinas, \\ C.P. 6109, CEP 13083-970, Campinas, SP, Brazil \\ Correspondence to: Erica Veronica Pardo, Departamento de Zoologia, Instituto de Biologia, Universidade Estadual \\ de Campinas, C.P. 6109, CEP 13083-970, Campinas, SP, Brazil, e-mail: evpardo@ sigmanet.com.br \\ Received November 22, 2002 - Accepted April 9, 2003 - Distributed May 31, 2004
}

(With 1 figure)

\begin{abstract}
Observations of the feeding behavior of Cirriformia filigera (Delle Chiaje, 1825) (Annelida: Polychaeta) from the intertidal zone of São Francisco and Engenho D'água beaches (São Sebastião, State of São Paulo) were made in the laboratory. This species, like other cirratulids, is a deposit feeder, feeding mainly on sediment surface with the aid of its grooved and ciliated palps, which are used to capture food particles. The worm lies just beneath the substrate surface in a J-shaped tube. When feeding, it extends up to 4 palps over the sediment surface, capturing food particles which pass down the groove of each palp directly to the mouth. Only fine sand grains are ingested. The worm frequently extends 4 branchial filaments into the overlying water for aeration. When it moves with the prostomium sideways, it collects and transports sand grains that pass backwards along its ventral region until reaching the middle part of its body. Next, the parapodia and palps move the sand grains to the dorsal posterior end of the animal, covering this area with sand. Some sand grains are also ingested as the worm moves.
\end{abstract}

Key words: feeding, Cirratulidae, Annelida, Polychaeta, Cirriformia filigera.

\section{RESUMO}

\section{Comportamento alimentar do cirratulídeo Cirriformia filigera (Delle Chiaje, 1825) (Annelida: Polychaeta)}

Observações sobre o comportamento alimentar de Cirriformia filigera, procedente da região entremarés das praias São Francisco e Engenho D'água (São Sebastião, SP), foram realizadas em laboratório. Constatouse que essa espécie, assim como os cirratulídeos de um modo geral, alimenta-se de depósitos, principalmente de superfície, utilizando seus palpos sulcados e ciliados na captura e ingestão de alimento. Durante a alimentação, expõe até quatro palpos para fora do sedimento, tateando a superfície e capturando partículas. O alimento coletado desliza pelos sulcos dos palpos em direção à boca. Observou-se que apenas areia fina foi ingerida. Cirriformia filigera permaneceu, durante o período, em tubos em forma de J, logo abaixo da superfície do sedimento. Quatro filamentos branquiais permaneciam, com freqüência, acima da superfície do substrato, proporcionando melhor oxigenação. Ao se deslocarem, com o prostômio executando movimentos laterais, empurram os grãos de areia para trás, para a região ventral, e, ao alcançarem a região mediana do corpo, os grãos de areia são transferidos para a parte dorsal-posterior pelos parapódios e palpos, onde ficam agrupados. Foi observada ingestão de grãos durante o deslocamento do animal.

Palavras-chave: alimentação, Cirratulidae, Annelida, Polychaeta, Cirriformia filigera.

\section{INTRODUCTION}

There is a considerable variety of feeding modes and associated structures among polychaete annelids. The cirratulids are selective deposit feeders, using their palps to capture food (Dales, 1970; Fauchald \& Jumars,
1979). Cirratulids, common in intertidal muddy substrates (George, $1964 \mathrm{a}, \mathrm{b}$ ), are burrowers, remaining just below the sediment surface, under stones and mixed with shells (Courtney, 1958; Warren, 1981; Bestwick et al., 1989; Blake, 1996) or associated with algae (Blake, 1996). Some species can burrow into corals 
and calcareous substrates, or even build calcareous tubes (Fauchald \& Jumars, 1979).

The polychaete Cirriformia filigera reaches a length of $250 \mathrm{~mm}$ (Day, 1967). It has a wedge-shaped prostomium that lacks prostomial appendages, and has grooved ciliate tentacular cirri (palps) on the anterior segments (between setigers 4 and 6) posterior to the first branchiae. The parapodia are poorly developed and have long branchiae extending dorso-laterally from most of the segments; some of these branchiae remain exposed on the sediment surface, as do the palps. The parapodia have capillary and sigmoid acicular setae.

Like others of its congeners, C. filigera is normally found in anoxic environments, being quite tolerant of low oxygen concentrations. Cirriformia tentaculata, for example, shows respiratory adaptations such as oxygen uptake rate reduction during periods of low oxygen concentration (Flattely, 1916; Warren, 1981; Bestwick et al., 1989).

The cirratulids are found worldwide (Pettibone, 1982) and Cirriformia filigera occurs on both sides of the North Atlantic and in southern Brazil (Hartman, 1951). On the northern coast of State São Paulo, it is common in sandy beaches, in fine to coarse sand mixed with rocks (Rizzo, 2000). Although this species is abundant in different kinds of marine environments and is taxonomically well known (Hartman, 1956, 1966; Imajima \& Hartman, 1964; Fauchald, 1977; Wolf, 1984; Blake, 1996), its biology has been the subject of few studies (Flattely, 1916; Courtney, 1958; George, 1964 a, b; Dales, 1970; Fauchald \& Jumars, 1979; Warren, 1981; Bestwick et al., 1989). The objective of the present investigation was to study aspects of the feeding behavior, including food capture and ingestion, of Cirriformia filigera.

\section{PROCEDURES}

Cirriformia filigera (Fig. 1) was collected from São Francisco $\left(23^{\circ} 44.8^{\prime} \mathrm{S}\right.$ and $\left.45^{\circ} 24.7^{\prime} \mathrm{W}\right)$ and Engenho D'Água $\left(23^{\circ} 47.8^{\prime} \mathrm{S}\right.$ and $\left.45^{\circ} 22.9^{\prime} \mathrm{W}\right)$ beaches on São Sebastião Channel (São Sebastião, State of São Paulo). São Francisco Beach is located on the mainland, and Engenho D'Água Beach is on São Sebastião Island. These beaches share similar environmental characteristics, with gentle slopes, narrow intertidal zones, and substrates consisting of mixed sand and stones of different sizes (Denadai \& Amaral, 1999).

From January through September 1998, specimens of $C$. filigera about $32 \mathrm{~mm}$ long and $1 \mathrm{~mm}$ wide (diameter) were collected from the intertidal zones of both beaches during low tide. The worms, together with sediment from the same localities, were placed in small transparent plastic pots ("aquaria") with 200 $\mathrm{ml}$ capacity (diameter $65.2 \mathrm{~mm}$, height $60 \mathrm{~mm}$ ). The aquaria were covered with nylon mesh $(0.03 \mathrm{~mm}$ mesh size), which allowed the water to circulate and prevented the worms from escaping. At different times during the study, 3 to 5 aquaria, each containing 2 to 5 worms, were set up. The aquaria were then placed in a plastic cube (length $45 \mathrm{~cm}$, width $28 \mathrm{~cm}$, height $16 \mathrm{~cm}$ ), under running water piped in directly from the sea, at the University of São Paulo Marine Biology Center Laboratory during the observation period.

Observations on feeding behavior began immediately after the flowing-water system was set up, and the movements of the animals were observed soon after they buried themselves in the sediment. All the observations were done with the aid of a stereoscopic microscope under normal illumination when the worms were in the aquaria. When the worms were placed in Petri dishes with small amounts of sediment, the light was covered with a transparent red paper filter, to reduce the light intensity and stress on the animals. Some observations of animals buried near the transparent side of an aquarium could be made with the aid of a hand lens. The worms were observed in 10 sessions for a total of about $19 \mathrm{~h}$.

In order to test the behavioral reactions of this species, live plankton was offered as food. The gut contents of six individuals were examined to evaluate the size of the sediment particles ingested.

\section{RESULTS}

In the laboratory, the specimens of Cirriformia filigera constructed fragile tubes cemented by a fine layer of mucus, which were easily destroyed by touching. The J-shaped tubes did not open to the sediment surface and remained completely covered by the sediment. A worm typically maintained either its entire body or about $2 / 3$ of its length in a vertical position, and the rest of the body horizontal (in a J) within the tube, with 3 or 4 anterior branchial filaments extending out of the sediment (Fig. 1A). Sometimes 1 or 2 posterior branchiae were also exposed, extending directly out of the sediment about $3 \mathrm{~mm}$ from the anterior branchiae (Fig. 1B). The Jposition of the individuals buried in the substrate was observed in animals placed next to the transparent walls of the aquaria. 

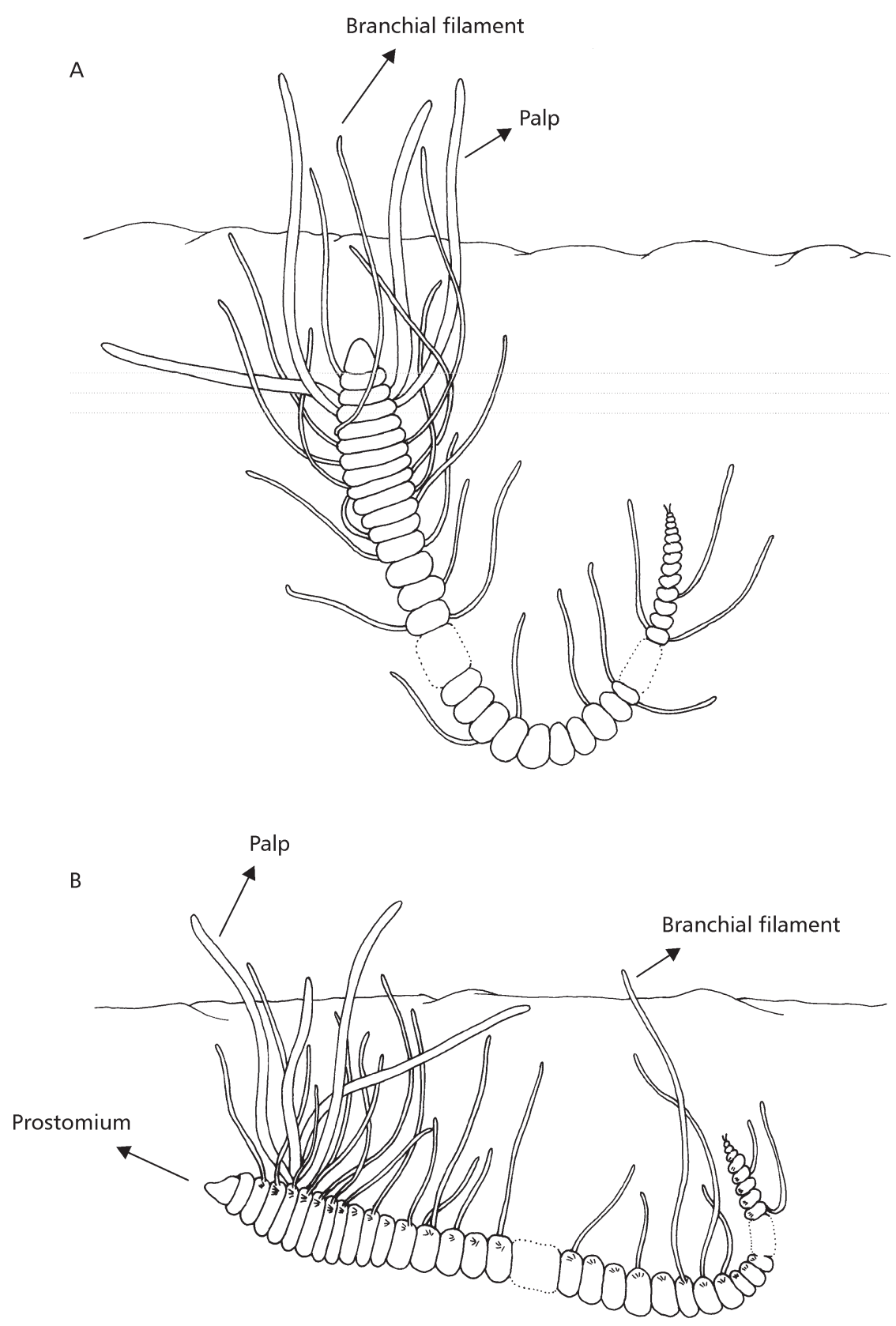

Fig. 1 - Cirriformia filigera in a J-shaped position in the sediment (A), and holding the posterior branchial filaments out of the sediment $(\mathrm{B})$.

When $C$. filigera was feeding, in addition to the branchiae it extended 3 or 4 palps out of the tube and over the sediment. Next, it moved the grooved (ciliate) part of the palps over the substrate, as if tasting the surface, in foraging. In this way it captured primarily fine particles and some coarser grains, which passed along the groove of each palp until they arrived at the point where the palp extended from the burrow. There, the coarser particles were retained while the finer particles continued to move along the ciliated 
groove toward the mouth. Repeatedly, the palps with adherent finer particles were completely retracted into the sediment and then exposed again, now clean. Feeding activity continued for periods of about $1 \frac{1}{2} \mathrm{~h}$ or longer. The palps frequently changed position in the sediment, so that the polychaete could forage in a complete circle.

The gut contents of $C$. filigera contained, besides small invertebrates such as foraminiferans and radiolarians, some diatom species, plant detritus, and sand grains varying from 15 to $222 \mu \mathrm{m}$ in diameter. As part of the observations, live plankton was twice offered to $C$. filigera, but was rejected in both trials.

When placed in a Petri dish with a small quantity of sediment and shielded from light, a worm typically proceeded slowly across the dish, with the palps and branchiae turned posteriorly, leaving the prostomium free. As it moving under a small amount of sediment, the worm pushed the sand grains backward with lateral movements of its prostomium. These grains, adhering to the mucus, were arranged in a row on the ventral part of the body up to approximately the middle region. Then they were transferred to the dorsum with the aid of the parapodia, and slowly piled onto the posterior part by the palps and branchiae, eventually covering the posterior part completely. As the animal advanced over the plate, some sand grains were sucked in by its mouth, as if aspirated, and were ingested. When the light was intensified by removing the cover, the worm drew the sediment near its body and remained immobile; when the light was decreased it again began to move. On being transferred to a dish with a small amount of sediment, a worm always moved toward the area with more sediment.

In order to observe the behavior of the animals in different situations, part of the water in the aquaria was removed, leaving only about a $0.5 \mathrm{~mm}$ layer above the sediment surface. In these conditions, food capture by the palps was not observed; nevertheless, the branchiae continued to be extended outside the sediment. When the branchiae or palps were touched, they were immediately retracted within the sediment, and after about 1 minute were exposed again.

\section{DISCUSSION AND CONCLUSIONS}

The few observations of cirratulid feeding behavior have shown clearly that foraging, e.g., the capture and size selection of food particles, is performed by the palps. According to Courtney (1958), the palps enable the animal to remain in its burrow while feeding upon surface detritus. Dales (1970) stated that cirratulids do not feed exclusively with their palps, and noted that this tendency to feed with the help of the palps is most evident in species of the genus Dodecaceria. In the present study, individuals of Cirriformia moving in Petri dishes occasionally sucked in and ingested some sand grains directly with the mouth. Dales (1970) noted that cirratulids may also feed with the aid of a prehensile tongue, a remnant of the archiannelid buccal bulb; the suction activity observed in the present study could have been performed with such a tongue. Flattely (1916) stated that Cirriformia tentaculata feeds by suction and that the sensitive edge of the flaps of the ventral side of the peristomium is used to select smaller food particles.

These laboratory observations indicate that $C$. filigera feeds selectively on surface deposits, and uses its grooved palps to capture food. According to Fauchald \& Jumars (1979), all cirratulids are deposit feeders, and select for both composition and size of the particles ingested. These authors observed two species, Cirriformia luxuriosa and C. spirabrancha in aquaria and found that the composition of the sediment particles changed, depending on where the worms were located.

In laboratory studies of particle selection, Taghon \& Jumars (1984) established that depositfeeding polychaetes of the families Ampharetidae and Spionidae increased their ingestion of particles in proportion to the protein content. These authors were questioning whether this increased ingestion rate might be a passive mechanism related to the greater adhesion of proteins to the mucus secreted by the palps; they concluded that the animals were actively controlling particle ingestion. It must be emphasized that these were laboratory experiments, using artificial particles, and that feeding in the natural environment is somewhat limited, mainly by the quantity and quality of available food. According to Taghon (1982), separation of an animal from the array of environmental factors to which it is subject cannot result in exact observations of its natural foraging behavior.

As observed in many species, particle selection probably occurs when there is a large amount of particles available; if particles are scarce the animal could show an opportunistic feeding behavior. 
Particles may also be rejected during the digestive process.

According to Blake (1996), cirratulids may deposit-feed at the sediment surface, below it, or both. In the present study, $C$. filigera was only observed feeding at the surface. However, its habit of burying itself may have prevented observation of subsurface feeding, even for individuals positioned at the sides of the aquaria. The behavior of the animals in the Petri dishes, in which they were seen to ingest particles directly with their mouths, might indicate that they normally feed on subsurface sediments. According to most investigators, cirratulids use mainly their palps to capture food (Fauchald \& Jumars, 1979).

The movements of the individuals through the fine sand layer in the Petri dishes are probably similar to their movements within the substrate, which cannot be observed when the animals are totally buried.

The fragile J-shaped tubes constructed by the cirratulids are not real tubes, but only a fine layer of sand grains cemented with mucus, which easily disintegrate when touched. According to Flattely (1916), the mucus produced by the body of the worm adheres to the sand particles and probably keeps the tube walls intact. The J-shape of these tubes may also be revealed by the position of the animal in the sediment, when it keeps both 3 or 4 anterior branchiae and 1 or 2 posterior branchiae exposed. This position of the animal in the sediment also could help its oxygen uptake during low tides and/or low oxygen conditions.

Cirriformia filigera always held its branchiae out of the sediment, even when little water was left in the aquarium, in order to maintain the supply of oxygen. This behavior is an adaptation to the low-oxygen environments where the species is normally found (Courtney, 1958; George, 1964a; Warren, 1981; Bestwick et al., 1989). Courtney observed that Cirriformia tentaculata can tolerate low oxygen levels for 14 to 16 hours. According to Bestwick et al. (1989), species of Cirriformia that live in anoxic environments maintain their oxygen supply by extending their branchiae out of the sediment, even at low tides, if a thin layer of water still remains. By leaving their branchiae exposed on the surface, the worms become subject to predation, especially at low tide. When they are touched, their only defense is to burrow more deeply (Bestwick et al., 1989), and rapidly retract their palps and branchiae into the tube. According to George (1964b), the mucous secretion from the body surface in Cirriformia tentaculata, a very similar species to $C$. filigera, has a flavor that is disagreeable to fish.

Acknowledgments - We would like to thank E. Soares Marinho, A. Máximo Rosa (UNICAMP), and the CEBIMar technicians, who assisted with the fieldwork, and Tatiana Menchini Steiner for the drawings. We are particularly grateful to the Centro de Biologia Marinha (CEBIMar, USP) for logistical support. This research was supported by grants from the Fundação Coordenação de Aperfeiçoamento de Pessoal de Nível Superior (CAPES) and from the Fundo de Apoio à Pesquisa (FAEP, UNICAMP). Dr. Janet W. Reid translated the text into English.

\section{REFERENCES}

BESTWICK, B. W., ROBBINS, I. J. \& WARREN, L. M., 1989, Metabolic adaptations of the intertidal polychaete Cirriformia tentaculata to life in an oxygen-sink environment. J. Exp. Mar. Biol. Ecol., 125: 193-202.

BLAKE, J. A., 1996, Family Cirratulidae Ryckholdt, 1851 Including a revision of the genera and species from the Eastern North Pacific, pp. 263-384. In: J. A. Blake, B. Hilbig \& P. H. Scott (eds.), The Annelida Part 3 - Polychaeta: Orbiniidae to Cossuridae. Vol. 6. Series: Taxonomic Atlas of the Benthic Fauna of the Santa Maria Basin and the Western Santa Barbara Channel. Santa Barbara Museum of Natural History, Santa Barbara, California.

COURTNEY, W. A. M., 1958, Certain aspects of the biology of the cirratulid polychaetes. Thesis submitted to the University of London for the degree of Doctor of Philosophy, 177p.

DALES, R. P., 1970, Annelids. $2^{\text {nd }}$ Ed. London: Hutchinson \& Co. (Publishers) LTD, 198p.

DAY, J. H., 1967, Polychaeta of Southern Africa. Part 2. Sedentaria. London, British Museum of Natural History, Publ. no. 656,420 p.

DENADAI, M. R. \& AMARAL, A. C. Z., 1999, A comparative study of the intertidal molluscan community in sandy beaches, São Sebastião Channel, São Paulo State, Brazil. Bull. Mar. Sci., 65: 91-103.

FAUCHALD, K., 1977, Polychaetes from intertidal areas in Panama, with a review of previous shallow-water records. Smithson. Contrib. Zool., (221): 1-81.

FAUCHALD, K. \& JUMARS, P. A., 1979, The diet of worms: a study of polychaete feeding guilds. Oceanogr. Mar. Biol. Ann. Rev., 17: 193-284.

FLATTELY, F. W., 1916, Notes on the ecology of Cirratulus (Audouinia) tentaculatus (Montagu). J. Mar. Biol. Ass. U.K., 11: 60-70.

GEORGE, J. D., 1964a, Organic matter available to the polychaete Cirriformia tentaculata (Montagu) living in an intertidal mud flat. Limnol. Oceanogr., 9: 453-455.

GEORGE, J. D., 1964b, The life history of the cirratulid worm, Cirriformia tentaculata, on an intertidal mudflat. J. Exp. Mar. Biol. Ecol., 44: 47-65.

HARTMAN, O., 1951, The littoral marine annelids of the Gulf of Mexico. Publs. Inst. mar. Sci., 2: 7-123. 
HARTMAN, O., 1956, Polychaetous annelids erected by Treadwell, 1891 to 1948 , together with a brief chronology. Bull. Am. Mus. Nat. Hist., 109: 239-310.

HARTMAN, O., 1966, Polychaetous annelids of the Hawaiian Islands. Occas. Pap. Bernice P. Bishop Mus., 23(11): 163252.

IMAJIMA, M. \& HARTMAN, O., 1964, The Polychaetous annelids of Japan. Part II. Occas. Pap. Allan Hancock Fdn., (6): 239-452.

PETTIBONE, M. H., 1982, Annelida, pp. 1-43. In: S. P. Parker (ed.), Synopsis and Classification of Living Organisms. McGraw-Hill, Inc., New York.

RIZZO, A. E., 2000, Temporal variation of annelids in the intertidal zone of beaches of São Sebastião Channel, southern Brazil. J. Mar. Biol. Ass. U.K., 80: 1007-1017.
TAGHON, G. L., 1982, Optimal foraging by deposit-feeding invertebrates: roles of particle size and organic coating. Oecologia, 52: 295-304.

TAGHON, G. L. \& JUMARS, P. A., 1984, Variable ingestion rate and its role in optimal foraging behavior of marine deposit feeders. Ecology, 65: 549-558.

WARREN, L. M., 1981, Respiratory adaptations to the temporary hypoxia by the polychaete Cirriformia tentaculata. Comp. Biochem. Physiol., 69A: 321-324.

WOLF, P. S., 1984, Family Cirratulidae Carus, 1863, pp. 12.112.12. In: J. M. Uebelacker \& P. J. Johnson (eds.), Taxonomic Guide to the Polychaetes of the Northern Gulf of Mexico. Vol. 2, Mobile, Alabama, Barry A. Vittor \& Associates. 